\title{
Status Epilepticus
}

\author{
Syndi Seinfeld ${ }^{1}$, Howard P. Goodkin ${ }^{2}$, and Shlomo Shinnar ${ }^{3}$ \\ ${ }^{1}$ Virginia Commonwealth University, Richmond, Virginia 23298-0211 \\ ${ }^{2}$ University of Virginia, Charlottesville, Virginia 22908 \\ ${ }^{3}$ Comprehensive Epilepsy Management Center, Montefiore Medical Center, Albert Einstein College \\ of Medicine, New York, New York 10467 \\ Correspondence: hpg9v@virginia.edu
}

\begin{abstract}
Although the majority of seizures are brief and cause no long-term consequences, a subset is sufficiently prolonged that long-term consequences can result. These very prolonged seizures are termed "status epilepticus" (SE) and are considered a neurological emergency. The clinical presentation of SE can be diverse. SE can occur at any age but most commonly occurs in the very young and the very old. There are numerous studies on SE in animals in which the pathophysiology, medication responses, and pathology can be rigorously studied in a controlled fashion. Human data are consistent with the animal data. In particular, febrile status epilepticus (FSE), a form of SE common in young children, is associated with injury to the hippocampus and subsequent temporal lobe epilepsy (TLE) in both animals and humans.
\end{abstract}

Ceizures are typically time-limited events that $\checkmark$ do not require emergent intervention or cause any lasting consequences. The exceptions are prolonged seizures, otherwise known as status epilepticus (SE), which are the subject of this article.

\section{DEFINITION}

The precise definition of SE depends on the context. Historically, the definition was based on the seizure being "long enough" to cause damage or, in the words of Gastaut (1983), "an enduring epilepticus condition." "Long enough" was originally defined as $60 \mathrm{~min}$ but was then lowered to $30 \mathrm{~min}$ (Commission on Epidemiology Prognosis 1993; Dodson et al. 1993) after it was shown that seizures of 40 to $45 \mathrm{~min}$ in ado- lescent baboons cause pathological changes even if the animals were ventilated and paralyzed (Meldrum and Horton 1973). This remains the current definition when studying the consequences of prolonged seizures.

More recent conceptual models of the definition of SE are based on the fact that most seizures are self-limited. SE can then be thought of as the failure of the inhibitory mechanisms that ordinarily terminate a seizure. Without such mechanisms and in the absence of an intervention, all seizures would not stop and would end up as SE. Based on this concept, the definition of SE is based on the time that one needs to intervene to stop the seizure. In other words, when is a seizure unlikely to stop soon unless a medication is used to stop it? This definition of SE was never based on $30 \mathrm{~min}$ and

Editors: Gregory L. Holmes and Jeffrey L. Noebels

Additional Perspectives on Epilepsy: The Biology of a Spectrum Disorder available at www.perspectivesinmedicine.org

Copyright (C) 2016 Cold Spring Harbor Laboratory Press; all rights reserved; doi: 10.1101/cshperspect.a022830

Cite this article as Cold Spring Harb Perspect Med 2016;6:a022830 
S. Seinfeld et al.

all the clinical trials and guidelines suggest that $\sim 5 \mathrm{~min}$ is the appropriate time to intervene for convulsive seizures (Dodson et al. 1993; Lowenstein et al. 1999; Shinnar et al. 2001a).

Recently, the International League Against Epilepsy (ILAE) Task Force for the classification of SE developed a revised definition of SE that incorporates both these features (Trinka et al. 2015). In this new definition, there are two time points for SE, T1, and T2. T1, which is when treatment should be initiated, is $5 \mathrm{~min}$ for convulsive SE based on studies that showed a seizure lasting $5 \mathrm{~min}$ is likely to be prolonged (Shinnar et al. 2001a; Hesdorffer et al. 2011). In contrast, $\mathrm{T} 2$, which is defined as the time point at which long-term consequences may occur, continues to be $30 \mathrm{~min}$. For the purposes of this review that focuses on the pathophysiology and outcomes rather than on treatment, we will continue to use the 30-min definition, which remains appropriate for this setting.

\section{CLASSIFICATION}

Although physicians often use the word "status" to denote an episode of generalized convulsive SE (e.g., tonic clonic SE), the clinical presentation of SE is broad. The seizures of SE can be either focal or generalized in onset and either convulsive or nonconvulsive in presentation. During SE, consciousness can be preserved (e.g., focal motor SE), altered (e.g., complex partial SE), or completely lost in the absence of motor symptoms (e.g., absence SE or electrographic SE in the comatose patient in the intensive care unit [ICU] setting).

\section{EPIDEMIOLOGY}

SE has been the subject of many large epidemiologic studies. Avalue of up to 200,000 episodes per year was derived from a prospective, population-based study performed in Richmond, VA, in which the estimated incidence was 41 per 100,000 population (DeLorenzo et al. 1996). In a retrospective, population-based study performed in Rochester, MN, the age-adjusted incidence for the years 1965-1985 was 18.3 per 100,000 population (Hesdorffer et al. 1998).
This lower value is in keeping with rates obtained from studies performed in Switzerland, Germany, and Italy (Coeytaux et al. 2000; Knake et al. 2001; Vignatelli et al. 2003).

SE occurs at all ages but is most common at the extremes of life. In the Richmond study, the incidence was nearly 150 per 100,000 persons in children less than 1 yr of age. The incidence dropped to $<25$ per 100,000 persons by $5 \mathrm{yr}$ of age until it increased again to $>50$ per 100,000 persons after $40 \mathrm{yr}$ of age. In the Rochester study, the cumulative incidence was four per 1000 to age 75 and showed greater increase after age 60 (Hesdorffer et al. 1998). Further, SE of longer duration $(>2 \mathrm{~h}$ ) occurred more frequently among infants and the elderly compared with persons aged 1 to $65 \mathrm{yr}$ in that study. In another study (Wu et al. 2002), the incidence rate for children $<5$ yr was 7.5 per 100,000 and that in the elderly population was 22.3 per 100,000 .

\section{CAUSES}

The causes of SE are numerous (Maytal et al. 1989; Dodson et al. 1993). In general, etiologies are divided into "cryptogenic/unknown" when there is no clear known cause, "remote symptomatic" when there is a prior insult such as stroke or head trauma, and "acute symptomatic" when there is an acute neurological (stroke, head trauma, or central nervous system [CNS] infection) or systemic (electrolyte disturbance or hypoxia) cause or progressive neurological disorder. Febrile SE, which is technically a form of acute symptomatic SE, is usually classified separately because of the distinct clinical features and differential prognosis from other forms of acute symptomatic SE.

The causes of SE vary with age. In adults, common identifiable causes of SE include trauma, tumor, vascular disease, alcohol withdrawal, and noncompliance with antiseizure medications (Aminoff and Simon 1980; DeLorenzo et al. 1992; Lowenstein and Alldredge 1993). In contrast, in the pediatric population, the most common causes are unknown and remote symptomatic causes. In acute cases in children, the most common identifiable causes are fever 
and infection (Maytal et al. 1989; Shinnar et al. 1997).

In the prognosis section of this review, we focus on febrile SE. Febrile SE accounts for $\sim 25 \%$ of all pediatric SE and more than $2 / 3$ of SE in the second year of life (Shinnar et al. 1997). It is defined as an episode of SE that also meets the criteria for a febrile seizure: A seizure associated with a febrile illness in the absence of acute CNS infection, trauma, or electrolyte disturbances in a child with no prior history of afebrile seizures (see consensus.nih.gov/1980/ 1980FebrileSeizures023html.htm; Commission on Epidemiology 1993). It is a particularly interesting group to study because of its epidemiological association with hippocampal sclerosis and temporal lobe epilepsy (TLE) (Shinnar 2003).

A genetic predisposition to prolonged seizures has been supported by prior studies (Shinnar et al. 2001a; Corey et al. 2004). A classic example of a genetic predisposition to SE is Dravet syndrome, which can result from a mutation in the gene $(S C N 1 A)$ that encodes for the $\alpha$ subunit of voltage-gated sodium channels $\left(\mathrm{Na}_{\mathrm{V}} 1.1\right)$. Children with Dravet syndrome commonly present with a fever-associated episode of SE before 1 yr of age. But even in children without a defined gene mutation, there is clearly a familial predisposition to both febrile seizures and to SE including febrile status epilepticus (FSE).

\section{PATHOGENESIS}

Studies investigating the pathogenesis of SE have been performed primarily in animal models of convulsive SE induced using either a (1) chemoconvulsant, such as the muscarinic acid receptor agonist pilocarpine in isolation or in combination with lithium, or (2) electrical stimulation. Models of nonconvulsive SE (NCSE) are limited (Krsek et al. 2001; Wong et al. 2003; Arcieri et al. 2014), and none of the currently available models replicate the key components of the form of NCSE that occurs in the ICU setting. SE can be induced using hyperthermia in young rats and mice; however, to date, this "febrile SE" model has been primarily used to study the epileptogenic process and not SE per se (Dube et al. 2010; Patterson et al. 2014).

Why some seizures end spontaneously, whereas others become self-sustaining and persist for a prolonged period of time is not known. In its simplest terms, a failure for the seizure to stop could be the result of failed inhibition or persistent excitation. Increasingly, there is evidence to support both of these mechanisms.

The $\gamma$-aminobutyric acid type A $\left(\mathrm{GABA}_{\mathrm{A}}\right)$ receptor is a predominantly postsynaptic receptor that mediates both fast phasic (i.e., synaptic) and prolonged tonic inhibition as the result of a chloride flux that occurs on the receptor's binding of $\gamma$-aminobutyric acid (GABA). The receptor is a heteromeric, pentameric structure that can be formed from 16 subunits (Sieghart 2006). The majority of the $\mathrm{GABA}_{\mathrm{A}}$ receptors in the CNS are assembled from two copies of an $\alpha$, two copies of a $\beta$, and a single copy of either a $\gamma, \delta$, or $\varepsilon$ subunit. The receptor's subunit composition determines its cellular surface location and its pharmacological properties. For example, receptors with a $\gamma 2$ subunit can enter the synapse, whereas those with a $\delta$ subunit are perisynaptic in location. Further, receptors with a $\gamma$ subunit are sensitive to the benzodiazepines, whereas those receptors with a $\delta$ subunit are insensitive to these positive allosteric $\mathrm{GABA}_{\mathrm{A}}$ receptor modulators (Sieghart 2006).

The genesis and maintenance of SE correlates with a reduction in $\mathrm{GABA}_{\mathrm{A}}$-mediated inhibition (Kapur and Lothman 1989; Kapur et al. 1989). This reduction in GABA-mediated inhibition corresponds to a rapid modification in the postsynaptic principal neuron $\mathrm{GABA}_{\mathrm{A}}$ receptor population as shown by a reduction in the potency of GABA (Kapur and Coulter 1995). There is also a reduced potency of the $\mathrm{GABA}_{\mathrm{A}}$ receptor allosteric modulators $\mathrm{Zn}^{2+}$ and diazepam (Kapur and Macdonald 1997). Prior hypotheses offered to explain these changes in the postsynaptic $\mathrm{GABA}_{\mathrm{A}}$ receptor population included an altered structural composition of the receptors or posttranslational modifications directly affecting a receptor's single channel conductance and its response to allosteric modulators. 
S. Seinfeld et al.

Subsequent studies using in vitro and in vivo models of SE suggested a third possibility. Goodkin et al. (2005) observed that a prolonged period of increased neuronal activity in a network of cultured hippocampal neurons induced by removal of magnesium from the external medium led to a reduction in the amplitude of action-potential independent phasic GABA currents (mIPSCs). In the same study, it was observed that this increase in neuronal activity was also associated with a rapid increase in the intracellular accumulation of $\mathrm{GABA}_{\mathrm{A}}$ receptors containing a $\beta 2 / 3$ subunit. In subsequent experiments, several independent groups of investigators (Naylor et al. 2005; Goodkin et al. 2008; Terunuma et al. 2008) recorded mIPSCs from either dentate granule cells or CA1 pyramidal neurons in hippocampal slices acutely isolated from animals in SE induced using the combination of lithium and pilocarpine, or continuous hippocampal stimulation. Similar to the recordings from the cultured hippocampal neurons, the amplitude of the mIPSC was reduced. This reduction in the amplitude in the synaptic current corresponded to a reduction in the surface expression of both $\beta 2 / 3$ subunit and $\gamma 2$ subunit-containing $\mathrm{GABA}_{\mathrm{A}}$ receptors. As the mIPSC amplitude is dependent on the number of receptors within the synapse, these studies led to the hypothesis that activity-dependent trafficking of synaptic $\mathrm{GABA}_{\mathrm{A}}$ receptors leading to a decline in the surface expression of synaptic $\mathrm{GABA}_{\mathrm{A}}$ receptors is, in part, responsible for the rapid reduction in GABA-mediated inhibition that occurs during SE.

The phosphorylation and dephosphorylation of $\mathrm{GABA}_{\mathrm{A}}$ receptors by protein kinases and phosphatases is known to affect the trafficking of these receptors. Targeting of the trafficking machinery could prove to be a novel target for the treatment of SE, especially refractory SE that has become resistant to benzodiazepines (see section below on Treatment). Moss and colleagues (Terunuma et al. 2008) showed that during SE there is a reduction in the activity of $\beta 3$ subunit-associated protein kinase $\mathrm{C}(\mathrm{PKC})$ and an increase in the activity of $\beta 3$ subunit-associated protein phosphatase $2 \mathrm{~A}(\mathrm{PP} 2 \mathrm{~A})$. Increasing the activity of PKC in acutely obtained hippo- campal slices from SE-treated animals served to increase the percentage of phosphorylated receptors with a corresponding increase in the surface expression of the receptors and a restoration of the mIPSC amplitude. Other studies have shown that inhibitors of PP2A as well as protein phosphatase $2 \mathrm{~B}$ ( $\mathrm{PP} 2 \mathrm{~B}$; calcineurin) was also effective in modulating the activity-dependent trafficking of the $\mathrm{GABA}_{\mathrm{A}}$ receptors leading to similar restoration of the surface expression of the receptors and a restoration of the mIPSC amplitude (Eckel et al. 2015; Joshi et al. 2015). Future experiments in vivo are required to determine if activation of protein kinases or inhibition of phosphatases during SE alters the time course or treatment of SE.

The $\mathrm{GABA}_{\mathrm{A}}$ receptor $\delta$ subunit commonly assemblies with either an $\alpha 4$ or $\alpha 6$ subunit. This combination of subunits renders the receptor benzodiazepine-insensitive. These extrasynaptic receptors are sensitive to general anesthetics (Lees et al. 1998; Feng and Macdonald 2004; Feng et al. 2004) and to neurosteroids (Hosie et al. 2006). The surface expression of these receptors was not found to be reduced and may be increased after SE (Goodkin et al. 2008; Terunuma et al. 2008). There is recent evidence that targeting these receptors may prove to be efficacious in the treatment of SE. Grosenbaugh and Mott (2013) found that stirepentol, which is a positive allosteric modulator of $\mathrm{GABA}_{\mathrm{A}}$ receptors, including those with a $\delta$ subunit, was capable of terminating SE that was resistant to diazepam in an animal model of SE. Similarly, neuroactive steroids were effective in preventing chemoconvulsant-induced SE (Kokate et al. 1996) and were recently shown to be effective in terminating an episode of SE that had persisted for days and been refractory to medications, including anesthetics, in two pediatric patients (Broomall et al. 2014).

The excitatory amino acid glutamate acts through both ionotropic and metabotropic glutamate receptors. There is some evidence to support the idea that ionotropic $N$-methyl-Daspartate (NMDA) and $\alpha$-amino-3-hydroxy5-methyl-4-isoxazolepropionic acid (AMPA) receptors are involved in the generation and maintenance of SE (Mazarati and Wasterlain 
1999; Mikati et al. 1999; Mazarati et al. 2006). In contrast to the reduction in surface expression observed for the $\gamma 2$ subunit-containing $\mathrm{GABA}_{\mathrm{A}}$ receptors, Wasterlain and colleagues (Mazarati et al. 2006; Naylor et al. 2013; Wasterlain et al. 2013) showed an increase in the immunoreactivity of the NR1 NMDA receptor subunit on the cell surface of dentate granule cells in hippocampal slices that were acutely obtained after SE. This finding was confirmed using electron microscopic techniques and corresponded to an increase in the frequency and amplitude of NMDA receptor-mediated currents in recordings obtained from these cells.

AMPA receptors containing a GluA2 subunit with an arginine at the $\mathrm{Q} / \mathrm{R}$ editing site are calcium impermeable. AMPA receptors with a GluA2 subunit having a glutamine at the $\mathrm{Q} / \mathrm{R}$ editing site or those receptors lacking a GluA2 subunit are calcium permeable. Currents recorded from GluA2-lacking AMPA receptors are inwardly rectifying and philanthotoxin sensitive. Rajasekaran and colleagues (2012) studied hippocampal slices acutely obtained from animals at two different time points: $10 \mathrm{~min}$ and $60 \mathrm{~min}$ post-SE onset. At both time points, the surface expression of the GluA2 subunit was reduced. A novel finding was that although AMPA receptor currents recorded from CA1 neurons after 10 and 60 min of SE and DGCs after 10 min of SE were found to be inwardly rectifying and philanthotoxin sensitive, the recordings from DGCs after $60 \mathrm{~min}$ were not, providing evidence that the changes that occur during SE are both time-dependent and region specific.

Together, these modifications in the surface glutamate receptor pool compound the reduced inhibition that results from the internalization of the $\gamma 2$ subunit-containing $\mathrm{GABA}_{\mathrm{A}}$ receptors. These changes are further exacerbated by trafficking of other channels such as the Atype potassium channel (Lugo et al. 2008) and HCN channel that affect the intrinsic excitability of the neurons as well as changes in the trafficking of chloride transporters (Lee et al. 2010; Deeb et al. 2012; Silayeva et al. 2015) that result in chloride loading and a depolarizing response to GABA. Recently, selective inhibition of these chloride transporters was shown to lead to hyperexctibability and epileptiform discharges (Sivakumaran et al. 2015).

\section{MANAGEMENT}

The management of any patient presenting with an episode of SE begins with the ABCs (airway breathing and circulation). If available, the patient is often placed on a cardiac monitor and pulse oximeter with the application of supplemental oxygen if indicated. Once stabilized, care moves toward terminating the seizure, identifying the underlying etiology, and developing a management plan based on the individual needs of the patient.

The evaluation of SE should be tailored to each individual patient. Laboratory testing to be considered based on history and physical examination include blood glucose, electrolytes, magnesium, calcium, phosphorous, complete blood count, serum transaminases, and toxicology screen. If a person has a known diagnosis of epilepsy, levels of the antiseizure medications should be obtained to determine compliance and potentially future alterations in dosing.

For those patients who present with fever, cultures of bodily fluids (blood, urine, and cerebrospinal fluid [CSF]) should be considered and antibiotics may be required. Although CSF pleocytosis may occur without infection with reported values during an episode of SE in the absence of an insult being $28 \times 10^{6} / \mathrm{L}$ (Barry and Hauser 1994), the presence of white blood cells (WBCs) in the CSF should not simply be dismissed as a consequence of the seizure (Rossi et al. 1986; Woody et al. 1988; Frank et al. 2012). In young infants, a higher degree of clinical suspicion may be needed, even in the absence of a clear pleocytosis, because they are recognized to be at greater risk for presentation with CNS infection showing minimal signs (Rossi et al. 1986; Rider et al. 1995; Nigrovic et al. 2007).

There is an increasing recognition that SE can be associated with antibody-mediated immune encephalitis. Examples include antiglutamic acid decarboxylase antibodies, anti-NMDA receptor antibodies, and antivoltage-gated potassium channel antibodies. When one of these conditions is suspected, serum and CSF evalu- 
S. Seinfeld et al.

ation for the presence of these antibodies should be undertaken.

An electroencephalogram (EEG) is not immediately required for treatment, and the urgency of this test depends on the patient's clinical presentation and response to treatment. If a patient has continued abnormal movements or is not returning to baseline after emergent treatment then an EEG must be performed to evaluate for persistence of the SE. If EEG is not available, additional empiric therapy may be required if there is a concern for NCSE. NCSE was documented in up to $1 / 3$ of patients who were admitted to an ICU following treatment for an episode of convulsive SE (DeLorenzo et al. 1998; Tay et al. 2006; Sanchez Fernandez et al. 2014b). Other indications for emergent EEG in patients prone to or being treated for SE includes the use of neuromuscular blockade and high-dose suppressive therapy for the treatment of refractory SE (see section on Treatment).

Imaging of the head with either computed axial tomography (CT) or magnetic resonance imaging (MRI) may be required to identify hemorrhage, ischemia, or a mass. This imaging should not proceed until the patient is stable.

\section{TREATMENT}

Treatment for SE should begin promptly in an effort to reduce the morbidity and mortality associated with SE (see section on Prognosis), especially given evidence from animal (Meldrum and Horton 1973) and clinical studies (Fujikawa et al. 2000; Vespa et al. 2010) that the prolonged seizure may induce cerebral injury. The current consensus is that treatment should be initiated after $5 \mathrm{~min}$ in cases of convulsive SE (Trinka et al. 2015). Based on several randomized trials (Treiman et al. 1998; Alldredge et al. 2001; Silbergleit et al. 2012; Chamberlain et al. 2014), there is consensus that the first-line treatment is a benzodiazepine.

Unfortunately, despite the recognition for the need for early treatment of SE, the initial treatment and escalation to second and subsequent line agents is often delayed in both the inhospital and out-of-hospital settings. For the children enrolled in the FEBSTAT study (de- scribed below; Seinfeld et al. 2014), the median time from the seizure onset to initiation of treatment was $30 \mathrm{~min}$. In a recent study of 81 patients who were refractory to initial treatment for SE, the first, second, and third dosing were administered at a median of $28 \mathrm{~min}, 40 \mathrm{~min}$, and 50 min after onset (Sanchez Fernandez et al. 2015). These values stand in stark contrast to many guidelines that recommend initial treatment at 5 min after SE onset but are representative of how long it takes for emergency medical services (EMS) to arrive and for treatment to be started. These times are a major improvement over the more than median $2 \mathrm{~h}$ delay reported in the Veterans Administration Collaborative Trial (Treiman et al. 1998).

It is important to realize that more than half of cases of SE have no prior history of seizures (Dodson et al. 1993). Therefore, having abortive therapy at home is not an option for them. Unfortunately, even when home abortive therapy is available, it is often not used (Sanchez Fernandez et al. 2015). Thus, prehospital treatment protocols, which have been shown to be safe and effective in several excellent randomized controlled trials (RCTs), are of utmost importance (Alldredge et al. 2001; Silbergleit et al. 2012).

As noted, benzodiazepines (e.g., diazepam, lorazepam, and midazolam) should be used as the initial treatment of SE. The benzodiazepines are available in formulations that permit intravenous as well as rectal, intramuscular, and intranasal administration. If the seizure does not respond to the initial or a subsequent benzodiazepine administration, the other antiseizure medications that are used for SE can be loaded intravenously (IV). At this point, there are several medications that are widely used including fosphenytoin, levetiracetam, and valproate that have some evidence supporting their use but there is no clear data as to which is preferable. Phenobarbital is also effective but is not usually a first choice owing to the increased risk of sedation and respiratory depression, especially when used immediately following a benzodiazepine. Lacosamide, which has also been proposed as possibly effective, at this point has only anecdotal evidence to support its use although trials are starting. 
There are currently no comparative treatment trials to guide the selection of the most appropriate second line or subsequent medications after the initial failure of a benzodiazepine. The recently funded Established Status Epilepticus Treatment Trial (ESETT) intends to compare the effectiveness of fosphenytoin, levetiracetam, and valproic acid as second-line agents. This multicenter, randomized, doubleblind, comparative effectiveness trial will include adults and children $\geq 2$ yr of age with convulsive SE who did not respond to adequate doses of benzodiazepines (Bleck et al. 2013). The patients will be recruited by two national emergency research networks: Neurology Emergency Treatment Trials (NETT) network and Pediatric Emergency Care and Applied Research Network (PECARN).

Refractory SE is defined as seizures lasting longer than 60 min despite treatment with a benzodiazepine and an adequate loading dose of a standard intravenous antiseizure medication (Mayer et al. 2002; Sanchez Fernandez et al. 2014a). Risk factors for refractory SE include NCSE and focal motor seizures at onset (Mayer et al. 2002). Common causes of refractory SE include encephalitis as well as the syndrome of "febrile infection-related epilepsy syndrome" (FIRES) (Kramer et al. 2011).

SE resistant to standard management continuing for $>24 \mathrm{~h}$ has been labeled as super-refractory SE. It is estimated that $\sim 15 \%$ of all cases of convulsive SE admitted to hospital will fall into this category (Shorvon and Ferlisi 2011).

Many SE treatment protocols call for the administration of continuous intravenous infusion of antiseizure medications for the treatment of refractory and super-refractory SE (Shorvon 2011; Shorvon and Ferlisi 2011). Pentobarbital has been the agent most widely used of the intravenous medications for this purpose. Other agents have included midazolam, propofol, ketamine, high-dose phenobarbital, thiopental, lidocaine, and inhalational anesthetics (e.g., isoflurane). The use of these medications predisposes to the need for mechanical ventilation, hypotension, and infection. In addition, recent reports have suggested that the use of continuous intravenous infusions for the treatment of refractory SE increases the risk of death, independently of SE (Rossetti et al. 2011; Schmutzhard and Pfausler 2011; Kowalski et al. 2012; Hocker et al. 2013; Sutter et al. 2014).

Hypothermia, ranging from $20^{\circ} \mathrm{C}$ to $35^{\circ} \mathrm{C}$, has been used to treat refractory SE in adults and there are case series in pediatrics. In rats with SE evoked by perforant pathway stimulation, moderate hypothermia $\left(29^{\circ} \mathrm{C}-33^{\circ} \mathrm{C}\right)$ reduced the frequency and severity of the clinical motor seizures but not of the epileptiform discharges (Schmitt et al. 2006). In a similar model, deep hypothermia $\left(20^{\circ} \mathrm{C}\right)$ suppressed SE in $40 \%$ of rats (Kowski et al. 2012). In a large pediatric case series that used mild hypothermia to treat refractory SE, it was found that hypothermia decreased seizure burden during and after pediatric refractory SE and may prevent refractory SE relapse (Guilliams et al. 2013). However, it remains an experimental technique. Although appealing on a theoretical basis, hypothermia has not yet been shown to be effective or found widely used in clinical practice

\section{PROGNOSIS}

The cause of the SE, the patient's age and underlying medical conditions all contribute to the outcome of the patient. Overall, SE carries a 7\%-39\% mortality rate (Towne et al. 1994; DeLorenzo et al. 1996; Coeytaux et al. 2000; Knake et al. 2001; Novy et al. 2010).

In children, the mortality is substantially less than the overall rate and is reported as $<5 \%$ (Maytal et al. 1989; Dodson et al. 1993; DeLorenzo et al. 1996). In children, the primary determinant of mortality is etiology with essentially all cases in which mortality occurred associated with acute symptomatic seizures (meningitis, trauma, etc.) or progressive neurodegenerative diseases (Maytal et al. 1989). Duration is related to outcome as well; however, in many cases, duration is associated with etiology and the majority of the most prolonged cases of SE are owing to acute symptomatic causes. In the very young, morbidity and mortality are somewhat higher owing to the higher frequency of bad etiologies in the first year of life (Maytal et al. 1989; Shinnar et al. 1997). 
S. Seinfeld et al.

The highest mortality is in elderly patients, with SE leading to death in $>76 \%$ cases (Logroscino et al. 2002). This is likely due both to the high rate of causes with poor prognosis such as stroke, myocardial infarction, and other forms of ischemic brain injury and because of the reduced ability of the elderly to tolerate the extreme metabolic stress placed on the brain and the body by convulsive SE.

Although most patients who experience SE do not have epilepsy at the time of their presentation, $\sim 1 / 4$ of children with epilepsy will experience at least one episode of SE (Sillanpaa and Shinnar 2002; Berg et al. 2004). Interestingly, the occurrence of SE is not random but seems to occur in specific subgroups. If a child does not have an episode of SE in the first few years of their epilepsy, they are extremely unlikely to ever do so. Conversely, if they do experience an episode of SE, there is a high likelihood they will do so again (Sillanpaa and Shinnar 2002). Not surprisingly, because in these cases the etiology of the SE is the underlying epilepsy, the morbidity and mortality in these cases of SE are low (Sillanpaa and Shinnar 2002; Tsetsou et al. 2015). In addition, despite the Gastaut definition of SE as causing "a fixed and enduring epilepticus” focus (Gastaut 1983), SE has only a modest influence on the probability of attaining remission (Sillanpaa et al. 1998) or leading to an epilepsy-related mortality (Sillanpaa and Shinnar 2010).

Of particular interest to the discussion of prognosis is FSE (Shinnar 2003). These prolonged febrile seizures constitute $~ 5 \%-9 \%$ of all febrile seizures (Berg and Shinnar 1996; Hesdorffer et al. 2011) and account for two-thirds of SE in the second year of life (Shinnar et al. 1997). They are associated with essentially no mortality or detectable short-term morbidity (Maytal and Shinnar 1990; Shinnar et al. 2001b). However, there is an association with subsequent TLE. Whether or not this is a causal association has been the subject of a long dispute (Shinnar 2003). In animal models of hyperthermic seizures in the immature brain, prolonged seizures of $60 \mathrm{~min}$ or more will cause development of TLE (Patterson et al. 2014). In humans, retrospective series of patients with
TLE undergoing evaluation for epilepsy surgery have found that $30 \%$ of these patients have a history of prolonged febrile seizures in childhood. Prospective studies to date have not found this association (Shinnar 2003) but the duration of followup has been short. The reported latency from the febrile SE to development of the TLE is 8-11 yr. The multicenter FEBSTAT study (Consequences of Prolonged Febrile Seizures in Children), which is investigating the relationship between FSE and subsequent TLE and hippocampal sclerosis, is prospectively addressing this controversy (Shinnar et al. 2008; Hesdorffer et al. 2012).

The FEBSTAT study cohort included 199 children with FSE. The children had baseline MRIs and EEGs within $72 \mathrm{~h}$ of the episode of febrile SE. Median seizure duration was more than an hour and the seizures proved surprisingly refractory to treatment (Seinfeld et al. 2014). Approximately $12 \%$ had evidence of increased hippocampal T2 signal on the baseline MRI (Shinnar et al. 2012). This increased signal was not seen in controls with brief febrile seizures. Other abnormalities included evidence of hippocampal malformations as a predisposing factor. As a group, the children with febrile SE had slightly smaller hippocampi than agematched controls with simple febrile seizures (Lewis et al. 2014). Review of their baseline EEGs showed that there was focal slowing or attenuation maximal in the temporal lobe in a substantial proportion of children, and the slowing and attenuation were highly associated with MRI evidence of acute hippocampal injury (Nordli et al. 2012). Spikes were not very frequent. This is consistent with an injury-based model leading to epilepsy, as focal slowing and attenuation are what one would expect in the presence of an injury.

At $1 \mathrm{yr}$, all the hippocampi that initially showed increased T2 signal shrank and the majority still showed evidence of increased T2 signal, thus meeting radiologic criteria for hippocampal sclerosis (Lewis et al. 2014). Acutely, the distribution of T2 signal was maximal in CA1. But, at $1 \mathrm{yr}$, the signal was more diffuse likely because CA1 had considerably shrank. The ADC map was initially consistent with ede- 
ma; but, at $1 \mathrm{yr}$, was more consistent with gliosis. These findings indicate that, in at least a proportion of cases, febrile SE can lead to hippocampal injury. It also suggests that the MRI can be a biomarker for those at high risk to develop subsequent hippocampal sclerosis and TLE (Gomes and Shinnar 2011; Patterson et al. 2014). Interestingly, in the children whose baseline MRIs after febrile SE were read as normal, the hippocampi did not shrink. However, nor did they grow, while in those children with simple febrile seizures, the expected hippocampal growth occurred. The median age was $15 \mathrm{mo}$, a time the hippocampi should be growing.

The FEBSTAT cohort is being followed long term, and the 5-yr assessment that includes memory, imaging, EEG, and development of epilepsy are almost completed. The plan is to follow this cohort until a minimum of $10 \mathrm{yr}$ to prospectively address the question of do prolonged febrile seizures lead to hippocampal sclerosis and TLE. Furthermore, a goal is to identify those at high risk to develop future trials of antiepileptogenesis agents. Such trials are already in the preclinical phase and hopefully will be translated to the human in the coming years. This is an attractive model both in animals and in the human to study antiepileptogenesis as the insult as well defined and not diffuse, there is a long latency, and we have potential biomarkers such as increased hippocampal T2 signal on MRI or focal slowing/attenuation on EEG that may help identify high-risk candidates. Although the latency to clinical TLE in the humans can be long, hippocampal volume loss occurs early so prevention of such volume loss offers an attractive target with biological plausibility of future studies.

\section{CONCLUSION}

SE is a life-threatening neurological emergency requiring prompt therapy as early treatment is recognized as essential to a favorable outcome. At the basic science level, there is a need to continue to define the molecular and cellular pathogenesis of SE along with understanding how brain development, etiology, or type of SE (e.g., febrile SE) may alter the pathogenesis. Clinical research in the near future will be focused on establishing the best agents to use when benzodiazepines fail, on developing better approaches to refractory SE, on altering clinical practice to reflect the data from the clinical trials and institute therapy early, and examining long-term consequences of SE, particularly febrile SE. The next generation of researchers will have the opportunity to extend these findings and focus on preventing the consequences of SE.

\section{REFERENCES}

Alldredge BK, Gelb AM, Isaacs SM, Corry MD, Allen F, Ulrich S, Gottwald MD, O’Neil N, Neuhaus JM, Segal $\mathrm{MR}$, et al. 2001. A comparison of lorazepam, diazepam, and placebo for the treatment of out-of-hospital status epilepticus. N Engl J Med 345: 631-637.

Aminoff MJ, Simon RP. 1980. Status epilepticus. Causes, clinical features and consequences in 98 patients. Am J Med 69: 657-666.

Arcieri S, Velotti R, Noe F, Carriero G, Cattalini A, Galbardi B, Gnatkovsky V, de Curtis M. 2014. Variable electrobehavioral patterns during focal nonconvulsive status epilepticus induced by unilateral intrahippocampal injection of kainic acid. Epilepsia 55: 1978-1985.

Barry E, Hauser WA. 1994. Pleocytosis after status epilepticus. Arch Neurol 51: 190-193.

Berg AT, Shinnar S. 1996. Complex febrile seizures. Epilepsia 37: 126-133.

Berg AT, Shinnar S, Testa FM, Levy SR, Frobish D, Smith SN, Beckerman B. 2004. Status epilepticus after the initial diagnosis of epilepsy in children. Neurology 63: 1027-1034.

Bleck T, Cock H, Chamberlain J, Cloyd J, Connor J, Elm J, Fountain N, Jones E, Lowenstein D, Shinnar S, et al. 2013. The established status epilepticus trial 2013. Epilepsia 54: 89-92.

Broomall E, Natale JE, Grimason M, Goldstein J, Smith CM, Chang C, Kanes S, Rogawski MA, Wainwright MS. 2014 Pediatric super-refractory status epilepticus treated with allopregnanolone. Ann Neurol 76: 911-915.

Chamberlain JM, Okada P, Holsti M, Mahajan P, Brown KM, Vance C, Gonzalez V, Lichenstein R, Stanley R, Brousseau DC, et al. 2014. Lorazepam vs diazepam for pediatric status epilepticus: A randomized clinical trial. JAMA 311: 1652-1660.

Coeytaux A, Jallon P, Galobardes B, Morabia A. 2000. Incidence of status epilepticus in French-speaking Switzerland: (EPISTAR). Neurology 55: 693-697.

Commission on Epidemiology and Prognosis, International League Against Epilepsy. 1993. Guidelines for epidemiologic studies on epilepsy. Epilepsia 34: 592-596.

Corey LA, Pellock JM, DeLorenzo RJ. 2004. Status epilepticus in a population-based Virginia twin sample. Epilepsia 45: $159-165$.

Deeb TZ, Maguire J, Moss SJ. 2012. Possible alterations in $\mathrm{GABA}_{\mathrm{A}}$ receptor signaling that underlie benzodiazepineresistant seizures. Epilepsia 53: 79-88. 
S. Seinfeld et al.

DeLorenzo RJ, Towne AR, Pellock JM, Ko D. 1992. Status epilepticus in children, adults, and the elderly. Epilepsia 33: $\mathrm{S} 15-25$.

DeLorenzo RJ, Hauser WA, Towne AR, Boggs JG, Pellock JM, Penberthy L, Garnett L, Fortner CA, Ko D. 1996. A prospective, population-based epidemiologic study of status epilepticus in Richmond, Virginia. Neurology 46: 1029-1035.

DeLorenzo RJ, Waterhouse EJ, Towne AR, Boggs JG, Ko D, DeLorenzo GA, Brown A, Garnett L. 1998. Persistent nonconvulsive status epilepticus after the control of convulsive status epilepticus. Epilepsia 39: 833-840.

Dodson WE, DeLorenzo RJ, Pedley TA, Shinnar S, Treiman DM, Wannamker BB. 1993. Treatment of convulsive status epilepticus. Recommendations of the Epilepsy Foundation of America's Working Group on Status Epilepticus. JAMA 270: 854-859.

Dube CM, Ravizza T, Hamamura M, Zha Q, Keebaugh A, Fok K, Andres AL, Nalcioglu O, Obenaus A, Vezzani A, et al. 2010. Epileptogenesis provoked by prolonged experimental febrile seizures: Mechanisms and biomarkers. $J$ Neurosci 30: 7484-7494.

Eckel R, Szulc B, Walker MC, Kittler JT. 2015. Activation of calcineurin underlies altered trafficking of $\alpha 2$ subunit containing $\mathrm{GABA}_{\mathrm{A}}$ receptors during prolonged epileptiform activity. Neuropharmacology 88: 82-90.

Feng HJ, Macdonald RL. 2004. Multiple actions of propofol on $\alpha \beta \gamma$ and $\alpha \beta \delta \mathrm{GABA}_{\mathrm{A}}$ receptors. Mol Pharmacol 66: 1517-1524.

Feng HJ, Bianchi MT, Macdonald RL. 2004. Pentobarbita differentially modulates $\alpha 1 \beta 3 \delta$ and $\alpha 1 \beta 3 \gamma 2 \mathrm{~L}_{\mathrm{GABA}}$ receptor currents. Mol Pharmacol 66: 988-1003.

Frank LM, Shinnar S, Hesdorffer DC, Shinnar RC, Pellock JM, Gallentine W, Nordli DR Jr, Epstein LG, Moshe SL, Lewis DV, et al. 2012. Cerebrospinal fluid findings in children with fever-associated status epilepticus: Results of the consequences of prolonged febrile seizures (FEBSTAT) study. J Pediatr 161: 1169-1171.

Fujikawa DG, Itabashi HH, Wu A, Shinmei SS. 2000. Status epilepticus-induced neuronal loss in humans without systemic complications or epilepsy. Epilepsia 41: 981991.

Gastaut H. 1983. Classification of status epilepticus. Adv Neurol 34: 15-35.

Gomes WA, Shinnar S. 2011. Prospects for imaging-related biomarkers of human epileptogenesis: A critical review. Biomark Med 5: 599-606.

Goodkin HP, Yeh JL, Kapur J. 2005. Status epilepticus increases the intracellular accumulation of $\mathrm{GABA}_{\mathrm{A}}$ receptors. J Neurosci 25: 5511-5520.

Goodkin HP, Joshi S, Mtchedlishvili Z, Brar J, Kapur J. 2008. Subunit-specific trafficking of $\mathrm{GABA}_{\mathrm{A}}$ receptors during status epilepticus. J Neurosci 28: 2527-2538.

Grosenbaugh DK, Mott DD. 2013. Stiripentol is anticonvulsant by potentiating GABAergic transmission in a model of benzodiazepine-refractory status epilepticus. Neuropharmacology 67: 136-143.

Guilliams K, Rosen M, Buttram S, Zempel J, Pineda J, Miller B, Shoykhet M. 2013. Hypothermia for pediatric refractory status epilepticus. Epilepsia 54: 1586-1594.
Hesdorffer DC, Logroscino G, Cascino G, Annegers JF, Hauser WA. 1998. Incidence of status epilepticus in Rochester, Minnesota, 1965-1984. Neurology 50: 735741.

Hesdorffer DC, Benn EK, Bagiella E, Nordli D, Pellock J, Hinton V, Shinnar S, Team FS. 2011. Distribution of febrile seizure duration and associations with development. Ann Neurol 70: 93-100.

Hesdorffer DC, Shinnar S, Lewis DV, Moshe SL, Nordli DR Jr, Pellock JM, MacFall J, Shinnar RC, Masur D, Frank LM, et al. 2012. Design and phenomenology of the FEBSTAT study. Epilepsia 53: 1471-1480.

Hocker SE, Britton JW, Mandrekar JN, Wijdicks EF, Rabinstein AA. 2013. Predictors of outcome in refractory status epilepticus. JAMA Neurol 70: 72-77.

Hosie AM, Wilkins ME, da Silva HMA, Smart TG. 2006. Endogenous neurosteroids regulate $\mathrm{GABA}_{\mathrm{A}}$ receptors through two discrete transmembrane sites. Nature 444: 486-489.

Joshi S, Rajasekaran K, Hawk KM, Brar J, Ross BM, Tran CA, Chester SJ, Goodkin HP. 2015. Phosphatase inhibition prevents the activity-dependent trafficking of $\mathrm{GABA}_{\mathrm{A}}$ receptors during status epilepticus in the young animal. Epilepsia 56: 1355-1365.

Kapur J, Coulter DA. 1995. Experimental status epilepticus alters $\gamma$-aminobutyric acid type A receptor function in CA1 pyramidal neurons. Ann Neurol 38: 893-900.

Kapur J, Lothman EW. 1989. Loss of inhibition precedes delayed spontaneous seizures in the hippocampus after tetanic electrical stimulation. J Neurophysiol 61: 427434.

Kapur J, Macdonald RL. 1997. Rapid seizure-induced reduction of benzodiazepine and $\mathrm{Zn}^{2+}$ sensitivity of hippocampal dentate granule cell $\mathrm{GABA}_{\mathrm{A}}$ receptors. J Neurosci 17: 7532-7540.

Kapur J, Stringer JL, Lothman EW. 1989. Evidence that repetitive seizures in the hippocampus cause a lasting reduction of GABAergic inhibition. J Neurophysiol 61: 417-426.

Knake S, Rosenow F, Vescovi M, Oertel WH, Mueller HH, Wirbatz A, Katsarou N, Hamer HM, Status Epilepticus Study Group H. 2001. Incidence of status epilepticus in adults in Germany: A prospective, population-based study. Epilepsia 42: 714-718.

Kokate TG, Cohen AL, Karp E, Rogawski MA. 1996. Neuroactive steroids protect against pilocarpine- and kainic acid-induced limbic seizures and status epilepticus in mice. Neuropharmacology 35: 1049-1056.

Kowalski RG, Ziai WC, Rees RN, Werner JK Jr, Kim G, Goodwin H, Geocadin RG. 2012. Third-line antiepileptic therapy and outcome in status epilepticus: The impact of vasopressor use and prolonged mechanical ventilation. Crit Care Med 40: 2677-2684.

Kowski AB, Kanaan H, Schmitt FC, Holtkamp M. 2012. Deep hypothermia terminates status epilepticus-An experimental study. Brain Res 1446: 119-126.

Kramer U, Chi CS, Lin KL, Specchio N, Sahin M, Olson H, Nabbout R, Kluger G, Lin JJ, van Baalen A. 2011. Febrile infection-related epilepsy syndrome (FIRES): Pathogenesis, treatment, and outcome: A multicenter study on 77 children. Epilepsia 52: 1956-1965. 
Krsek P, Mikulecka A, Druga R, Hlinak Z, Kubova H, Mares P. 2001. An animal model of nonconvulsive status epilepticus: A contribution to clinical controversies. Epilepsia 42: $171-180$

Lee HH, Jurd R, Moss SJ. 2010. Tyrosine phosphorylation regulates the membrane trafficking of the potassium chloride co-transporter KCC2. Mol Cell Neurosci 45: $173-179$.

Lees G, Edwards MD, Hassoni AA, Ganellin CR, Galanakis D. 1998. Modulation of $\mathrm{GABA}_{\mathrm{A}}$ receptors and inhibitory synaptic currents by the endogenous CNS sleep regulator cis-9,10-octadecenoamide (cOA). Br J Pharmacol 124: 873-882.

Lewis DV, Shinnar S, Hesdorffer DC, Bagiella E, Bello JA, Chan S, Xu Y, MacFall J, Gomes WA, Moshe SL, et al. 2014. Hippocampal sclerosis after febrile status epilepticus: The FEBSTAT study. Ann Neurol 75: 178-185.

Logroscino G, Hesdorffer DC, Cascino GD, Annegers JF, Bagiella E, Hauser WA. 2002. Long-term mortality after a first episode of status epilepticus. Neurology 58: 537 541.

Lowenstein DH, Alldredge BK. 1993. Status epilepticus at an urban public hospital in the 1980s. Neurology 43: $483-$ 488.

Lowenstein DH, Bleck T, Macdonald RL. 1999. It's time to revise the definition of status epilepticus. Epilepsia 40: $120-122$.

Lugo JN, Barnwell LF, Ren Y, Lee WL, Johnston LD, Kim R, Hrachovy RA, Sweatt JD, Anderson AE. 2008. Altered phosphorylation and localization of the A-type channel, Kv4.2 in status epilepticus. J Neurochem 106: 1929-1940.

Mayer SA, Claassen J, Lokin J, Mendelsohn F, Dennis LJ, Fitzsimmons BF. 2002. Refractory status epilepticus: Frequency, risk factors, and impact on outcome. Arch Neurol 59: $205-210$.

Maytal J, Shinnar S. 1990. Febrile status epilepticus. Pediatrics 86: 611-616.

Maytal J, Shinnar S, Moshe SL, Alvarez LA. 1989. Low morbidity and mortality of status epilepticus in children. Pediatrics 83: 323-331.

Mazarati AM, Wasterlain CG. 1999. N-methyl-D-asparate receptor antagonists abolish the maintenance phase of self-sustaining status epilepticus in rat. Neurosci Lett 265: $187-190$.

Mazarati AM, Liu H, DN, Wasterlain C. 2006. Self-sustaining status epilepticus. In Status epileptius: Mechanisms and management, pp. 209-228. The MIT Press, London.

Meldrum BS, Horton RW. 1973. Physiology of status epilepticus in primates. Arch Neurol 28: 1-9.

Mikati MA, Werner S, Gatt A, Liu Z, Rahmeh AA, Rachid RA, Stafstrom CE, Holmes GL. 1999. Consequences of $\alpha$ amino-3-hydroxy-5-methyl-4-isoxazolepropionic acid receptor blockade during status epilepticus in the developing brain. Brain Res Dev Brain Res 113: 139-142.

Naylor DE, Liu H, Wasterlain CG. 2005. Trafficking of $\mathrm{GABA}_{\mathrm{A}}$ receptors, loss of inhibition, and a mechanism for pharmacoresistance in status epilepticus. J Neurosci 25: 7724-7733.

Naylor DE, Liu H, Niquet J, Wasterlain CG. 2013. Rapid surface accumulation of NMDA receptors increases glu- tamatergic excitation during status epilepticus. Neurobiol Dis 54: 225-238.

Nigrovic LE, Kuppermann N, Macias CG, Cannavino CR, Moro-Sutherland DM, Schremmer RD, Schwab SH, Agrawal D, Mansour KM, Bennett JE, et al. 2007. Clinical prediction rule for identifying children with cerebrospinal fluid pleocytosis at very low risk of bacterial meningitis. JAMA 297: 52-60.

Nordli DR Jr, Moshe SL, Shinnar S, Hesdorffer DC, Sogawa Y, Pellock JM, Lewis DV, Frank LM, Shinnar RC, Sun S, et al. 2012. Acute EEG findings in children with febrile status epilepticus: Results of the FEBSTAT study. Neurology 79: $2180-2186$.

Novy J, Logroscino G, Rossetti AO. 2010. Refractory status epilepticus: A prospective observational study. Epilepsia 51: $251-256$.

Patterson KP, Baram TZ, Shinnar S. 2014. Origins of temporal lobe epilepsy: Febrile seizures and febrile status epilepticus. Neurotherapeutics 11: 242-250.

Rajasekaran K, Todorovic M, Kapur J. 2012. Calcium-permeable AMPA receptors are expressed in a rodent model of status epilepticus. Ann Neurol 72: 91-102.

Rider LG, Thapa PB, Del Beccaro MA, Gale JL, Foy HM, Farwell JR, Mendelman PM. 1995. Cerebrospinal fluid analysis in children with seizures. Pediatr Emerg Care 11: 226-229.

Rossetti AO, Milligan TA, Vulliemoz S, Michaelides C, Bertschi M, Lee JW. 2011. A randomized trial for the treatment of refractory status epilepticus. Neurocrit Care 14: $4-10$.

Rossi LN, Brunelli G, Duzioni N, Rossi G. 1986. Lumbar puncture and febrile convulsions. Helv Paediatr Acta 41: $19-24$.

Sanchez Fernandez I, Abend NS, Agadi S, An S, Arya R, Carpenter JL, Chapman KE, Gaillard WD, Glauser TA, Goldstein DB, et al. 2014a. Gaps and opportunities in refractory status epilepticus research in children: A multi-center approach by the Pediatric Status Epilepticus Research Group (pSERG). Seizure 23: 87-97.

Sanchez Fernandez I, Abend NS, Arndt DH, Carpenter JL, Chapman KE, Cornett KM, Dlugos DJ, Gallentine WB, Giza CC, Goldstein JL, et al. 2014b. Electrographic seizures after convulsive status epilepticus in children and young adults: A retrospective multicenter study. J Pediatr 164: 339-346 e331-332.

Sanchez Fernandez I, Abend NS, Agadi S, An S, Arya R, Brenton JN, Carpenter JL, Chapman KE, Gaillard WD, Glauser TA, et al. 2015. Time from convulsive status epilepticus onset to anticonvulsant administration in children. Neurology 84: 2304-2311.

Schmitt FC, Buchheim K, Meierkord H, Holtkamp M. 2006. Anticonvulsant properties of hypothermia in experimental status epilepticus. Neurobiol Dis 23: 689-696.

Schmutzhard E, Pfausler B. 2011. Complications of the management of status epilepticus in the intensive care unit. Epilepsia 52: 39-41.

Seinfeld S, Shinnar S, Sun S, Hesdorffer DC, Deng X, Shinnar RC, O'Hara K, Nordli DR Jr, Frank LM, Gallentine W, et al. 2014. Emergency management of febrile status epilepticus: Results of the FEBSTAT study. Epilepsia 55: $388-395$. 
S. Seinfeld et al.

Shinnar S. 2003. Febrile seizures and mesial temporal sclerosis. Epilepsy Curr 3: 115-118.

Shinnar S, Pellock JM, Moshe SL, Maytal J, O'Dell C, Driscoll SM, Alemany M, Newstein D, DeLorenzo RJ. 1997. In whom does status epilepticus occur: Age-related differences in children. Epilepsia 38: 907-914.

Shinnar S, Berg AT, Moshe SL, Shinnar R. 2001a. How long do new-onset seizures in children last? Ann Neurol 49: 659-664.

Shinnar S, Pellock JM, Berg AT, O’Dell C, Driscoll SM, Maytal J, Moshe SL, DeLorenzo RJ. 2001b. Short-term outcomes of children with febrile status epilepticus. Epilepsia 42: $47-53$.

Shinnar S, Hesdorffer DC, Nordli DR Jr, Pellock JM, O’Dell C, Lewis DV, Frank LM, Moshe SL, Epstein LG, Marmarou A, et al. 2008. Phenomenology of prolonged febrile seizures: results of the FEBSTAT study. Neurology 71: $170-176$.

Shinnar S, Bello JA, Chan S, Hesdorffer DC, Lewis DV, Macfall J, Pellock JM, Nordli DR, Frank LM, Moshe SL, et al. 2012. MRI abnormalities following febrile status epilepticus in children: The FEBSTAT study. Neurology 79: 871877.

Shorvon S. 2011. Super-refractory status epilepticus: An approach to therapy in this difficult clinical situation. Epilepsia 52: 53-56.

Shorvon S, Ferlisi M. 2011. The treatment of super-refractory status epilepticus: A critical review of available therapies and a clinical treatment protocol. Brain 134: $2802-$ 2818.

Sieghart W. 2006. Structure, pharmacology, and function of $\mathrm{GABA}_{\mathrm{A}}$ receptor subtypes. Adv Pharmacol 54: 231-263.

Silayeva L, Deeb TZ, Hines RM, Kelley MR, Munoz MB, Lee HH, Brandon NJ, Dunlop J, Maguire J, Davies PA, et al. 2015. KCC2 activity is critical in limiting the onset and severity of status epilepticus. Proc Natl Acad Sci 112: 3523-3528.

Silbergleit R, Durkalski V, Lowenstein D, Conwit R, Pancioli A, Palesch Y, Barsan W, Investigators N. 2012. Intramuscular versus intravenous therapy for prehospital status epilepticus. N Engl J Med 366: 591-600.

Sillanpaa M, Shinnar S. 2002. Status epilepticus in a population-based cohort with childhood-onset epilepsy in Finland. Ann Neurol 52: 303-310.

Sillanpaa M, Shinnar S. 2010. Long-term mortality in childhood-onset epilepsy. N Engl J Med 363: 2522-2529.

Sillanpaa M, Jalava M, Kaleva O, Shinnar S. 1998. Longterm prognosis of seizures with onset in childhood. $N$ Engl J Med 338: 1715-1722.

Sivakumaran S, Cardarelli RA, Maguire J, Kelley MR, Silayeva L, Morrow DH, Mukherjee J, Moore YE, Mather RJ, Duggan ME, et al. 2015. Selective Inhibition of KCC2 Leads to hyperexcitability and epileptiform discharges in hippocampal slices and in vivo. J Neurosci 35: 82918296.

Sutter R, Marsch S, Fuhr P, Kaplan PW, Ruegg S. 2014. Anesthetic drugs in status epilepticus: risk or rescue? A 6-year cohort study. Neurology 82: 656-664.

Tay SK, Hirsch LJ, Leary L, Jette N, Wittman J, Akman CI. 2006. Nonconvulsive status epilepticus in children: Clinical and EEG characteristics. Epilepsia 47: 1504-1509.

Terunuma M, Xu J, Vithlani M, Sieghart W, Kittler J, Pangalos M, Haydon PG, Coulter DA, Moss SJ. 2008. Deficits in phosphorylation of $\mathrm{GABA}_{\mathrm{A}}$ receptors by intimately associated protein kinase $\mathrm{C}$ activity underlie compromised synaptic inhibition during status epilepticus. $J$ Neurosci 28: 376-384.

Towne AR, Pellock JM, Ko D, DeLorenzo RJ. 1994. Determinants of mortality in status epilepticus. Epilepsia 35: $27-34$.

Treiman DM, Meyers PD, Walton NY, Collins JF, Colling C, Rowan AJ, Handforth A, Faught E, Calabrese VP, Uthman $\mathrm{BM}$, et al. 1998. A comparison of four treatments for generalized convulsive status epilepticus. Veterans Affairs Status Epilepticus Cooperative Study Group. $N$ Engl J Med 339: 792-798.

Trinka E, Cock H, Hesdorffer D, Rossetti AO, Scheffer IE, Shinnar S, Shorvon S, Lowenstein DH. 2015. A definition and classification of status epilepticus: Report of the ILAE Task Force on classification of status epilepticus. Epilepsia 56: $1515-1523$.

Tsetsou S, Novy J, Rossetti AO. 2015. Recurrence of status epilepticus: Prognostic role and outcome predictors. Epilepsia 56: 473-478.

Vespa PM, McArthur DL, Xu Y, Eliseo M, Etchepare M, Dinov I, Alger J, Glenn TP, Hovda D. 2010. Nonconvulsive seizures after traumatic brain injury are associated with hippocampal atrophy. Neurology 75: 792-798.

Vignatelli L, Tonon C, D’Alessandro R; Bologna Group for the Study of Status E. 2003. Incidence and short-term prognosis of status epilepticus in adults in Bologna, Italy. Epilepsia 44: 964-968.

Wasterlain CG, Naylor DE, Liu H, Niquet J, Baldwin R. 2013. Trafficking of NMDA receptors during status epilepticus: Therapeutic implications. Epilepsia 54: 78-80.

Wong M, Wozniak DF, Yamada KA. 2003. An animal model of generalized nonconvulsive status epilepticus: Immediate characteristics and long-term effects. Exp Neurol 183: 87-99.

Woody RC, Yamauchi T, Bolyard K. 1988. Cerebrospinal fluid cell counts in childhood idiopathic status epilepticus. Pediatr Infect Dis J 7: 298-299.

Wu YW, Shek DW, Garcia PA, Zhao S, Johnston SC. 2002. Incidence and mortality of generalized convulsive status epilepticus in California. Neurology 58: 1070-1076. 


\section{$\&_{\mathrm{CSH}}^{\infty} \&$ Cold Spring Harbor

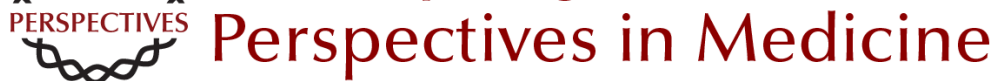

\section{Status Epilepticus}

Syndi Seinfeld, Howard P. Goodkin and Shlomo Shinnar

Cold Spring Harb Perspect Med 2016; doi: 10.1101/cshperspect.a022830

Subject Collection Epilepsy: The Biology of a Spectrum Disorder

The Epilepsy Spectrum: Targeting Future Research Challenges

Gregory L. Holmes and Jeffrey L. Noebels

Role of Sodium Channels in Epilepsy

David I. Kaplan, Lori L. Isom and Steven Petrou

\section{Mechanisms of Action of Antiseizure Drugs and the Ketogenic Diet Michael A. Rogawski, Wolfgang Löscher and Jong M. Rho}

Epilepsy and Autism

Ashura W. Buckley and Gregory L. Holmes

Immunity and Inflammation in Epilepsy Annamaria Vezzani, Bethan Lang and Eleonora Aronica

Hyperpolarization-Activated Cyclic Nucleotide-Gated (HCN) Channels in Epilepsy Gary P. Brennan, Tallie Z. Baram and Nicholas P. Poolos

The Role of Calcium Channels in Epilepsy Sanjeev Rajakulendran and Michael G. Hanna Interneuron Transplantation as a Treatment for Epilepsy

Robert F. Hunt and Scott C. Baraban
Common Mechanisms Underlying

Epileptogenesis and the Comorbidities of

Epilepsy

Andrey Mazarati and Raman Sankar

The Diathesis-Epilepsy Model: How Past Events Impact the Development of Epilepsy and Comorbidities Christophe Bernard

Potassium Channels in Epilepsy Rüdiger Köhling and Jakob Wolfart

GABAergic Synchronization in Epilepsy Roustem Khazipov

Status Epilepticus Syndi Seinfeld, Howard P. Goodkin and Shlomo Shinnar

Neonatal and Infantile Epilepsy: Acquired and Genetic Models Aristea S. Galanopoulou and Solomon L. Moshé

Epigenetics and Epilepsy David C. Henshall and Katja Kobow

Microcircuits in Epilepsy: Heterogeneity and Hub Cells in Network Synchronization Anh Bui, Hannah K. Kim, Mattia Maroso, et al.

For additional articles in this collection, see http://perspectivesinmedicine.cshlp.org/cgi/collection/ 